\title{
CUVÂNTUL ROSTIT DE ACTOR De la cuvântul scris la cuvântul celuilalt
}

\author{
Cătălina-Elena Mihăilă
}

DOI 10.46522/CT.2021.01.02

\begin{abstract}
The word spoken by the actor. From the written word to the other's word

Exceeding the level of everyday speech, the word spoken by the actor on stage aims to become a superior form of expression. Thus, we will follow a double approach of the word starting from the original word found in the dramatic text. On the one hand, we will look for that word which, taken from the written plan, is uttered following an act of creation, and the other hand, by inner assumption, we will follow the word that exceeds the level of auditory pleasure and is uttered under the imprint of an internal content.
\end{abstract}

\section{Keywords:}

written word, spoken word, internal content, communication, indoor laboratory

\section{De la „scris“ la „rostit“}

ncadrându-se în sfera fenomenelor artistice, teatrul ajunge, prin reprezentația scenică, la idealul de „formă superioară de exprimare“1 . Astfel, întregul arsenal de mij-

1. Ion Toboșaru, Principii generale de estetică, Cluj-Napoca, Editura Dacia, 1978, p. 8. 
loace de exprimare implicate în creația scenică se racordează în acest sens, tinzând spre perfecționare și expresivitate. Acest nivel înalt de exprimare poate fi tradus prin capacitatea de a transmite spectatorului unități de expresie atât prin intermediul imaginii, cât și al sunetului, captivându-l atât la nivel de percepție vizuală, cât și auditivă. Rangul de superioritate poate fi considerat atins în momentul în care formele de exprimare, de altfel exterioare, reușesc să comunice cu lumea lăuntrică a spectatorului. Din întreaga echipă de creatori care fundamentează spectacolul teatral, actorul este cel care dă senzația unei creații la vedere și în timp real, având posibilitatea unei comunicări directe. La o primă vedere, se pot distinge instrumentele exterioare la care apelează artistul, o aparență care nu poate fi suficientă în exprimare decât printr-o asumare, implicare și mobilare interioară, o conexiune veridică între spirit, suflet și trup. Această conexiune va conduce spre o echilibrare și o armonizare a mijloacelor de exprimare ale actorului, spre o comuniune a elementelor ce aparțin limbajelor implicate, un raport de coordonare între cuvânt, gest și elemente ce țin de expresivitatea facială.

Dincolo de forța și iscusința de a transmite prin intermediul elementelor de expresivitate facială sau corporală, interpretul dramatic se remarcă încă din cele mai îndepărtate vremuri prin modul de livrare a cuvântului impecabil rostit, care îl poate înscrie în categoria ,artiștii cuvântului““2. Șlefuirea acestui instrument de exprimare trebuie să îndrepte artistul spre asumarea rolului de „maestru al cuvântului rostit.“ ${ }^{\text {3 }}$

\subsection{Originea cuvântului rostit}

Izvorul acestui cuvânt pe care actorul urmează să îl rostească pe scenă se află în textul dramatic sub forma unității de bază a acestuia. Cuvântul scris este elementul de pornire în întreg laboratorul de creație al artistului dramatic, fapt pentru care acesta devine sursă principală în înțelegerea

$\diamond$

2. Lidia Sfîrlea, Pronunția românească literară - stilul scenic, București, Editura Academiei Republicii Socialiste Române, 1970, p. 17. 3. Ibidem, p. 17. 
personajului, a situațiilor, a relațiilor dramatice. Înțelegerea și apropierea de creația dramaturgului va putea fi sesizată și în felul în care cuvântul rostit va fi expediat. Astfel, artistul trebuie să decodeze textul dramatic și, mai ales, să descifreze amprenta proprie a fiecărui scriitor, acel stil pe care Tudor Vianu îl definea ca „ansamblul notațiilor pe care acesta le adaugă expresiilor sale tranzitive și prin care comunicarea sa dobândește un fel de a fi subiectiv. Îmbogățite cu aceste adaosuri, expresiile limbii se introduc în intimitatea unei individualități, într-o sferă proprie de a resimți lumea și viața““4.

\subsection{Transferul de la semn lingvistic grafic la rostit}

Transferul de la cuvântul scris la cel rostit va depinde și de gradul de oralitate a textului dramatic, prin acea aderare la stilul vorbit, „prin nimic esențial deosebit de vorbirea curentă, expresie vie, spontană, naturală a gândirii și simțirii noastre“" . Această definire a oralității poate fi considerată o oglindă a nivelului la care cuvântul scris trebuie să fie vorbit pe scenă. Dincolo de acest transfer de la element lingvistic grafic la unul rostit, se poate semnala o discrepanță între scris și vorbit, deoarece discutăm despre două sisteme diferite de semne ${ }^{6}$. De asemenea, actorul are responsabilitatea de a respecta și a nu denatura textul dramatic, dar nu se poate susține o exactitate în redarea acestuia, deoarece artistul „nu reproduce pur și simplu, ci interpretează, creează ${ }^{\text {" }}$. Premergător acestui transfer de la cuvântul reprezentat grafic la cel vorbit, se poate semnala o abordare obiectivă a textului scris care va îndruma spre o redare fidelă a ideilor și a emoțiilor transmise de creatorul originar al operei. Această abordare este surprinsă în

4. Apud D. Macrea, Contribuții la istoria lingvisticii și filologiei românești, București, Editura științifică și enciclopedică, 1978, p. 445.

5. Apud G. I. Tohăneanu, Dincolo de cuvânt, București, Editura științifică și enciclopedică, 1976, p. 119.

6. Eugenio Coseriu, Introducere in lingvistică, traducere de Elena Ardeleanu și Eugenia Bojoga, Cluj-Napoca, Editura Echinox, 1995, p. 127. 7. Lidia Sfîrlea, Pronunția românească literară-stilul scenic, ed. cit., p. 45. 
primele lecturări ale textului, conducând spre o rezonanță a artistului dramatic cu esențele surprinse în cuvântul scris. În urma înmagazinării sensurilor din text, odată cu punerea în mișcare în scenă a personajului, cuvântul scris va căpăta și el fizicalitate, va fi pus în mișcare, actorul având o preocupare sporită față de exprimarea orală, existând chiar o prioritate în conștiința acestuia față de sunet, în detrimentul literei, o disciplină și o preocupare în crearea sunetului ${ }^{8}$.

\subsection{A rosti}

Trecerea efectivă de la scriitură la sonoritate se produce prin procesul de rostire a cuvântului, rostire care nu trebuie să se oprească la o simplă pronunție, la o banală producere de sunete asamblate în cuvinte, propoziții și fraze. În urma unei confruntări între diferite definiții ale acestui concept de a rosti, Constantin Noica susținea că „A rosti rostuiește așadar rostul. Așa făcând, termenul rostire reintegrează ceea ce rostul pierduse, anume cuvântul.“9 Astfel, cuvântul nu poate fi doar rostit pe scenă, ci pronunțat cu un rost, cu atât mai mult cu cât acesta nu vine dintr-o necesitate organică specifică vorbirii, ci se va desprinde din memorie. Pericolul rostirii unui text memorat este acela de a fi doar redat, neasumat și, uneori, chiar lăsând senzația sonoră a unor vorbe știute pe dinafară. Rostirea cu specific artistic tinde spre a ,spune totul după o rânduială, și nu doar pe dinafarăa10, o asumare a cuvântului ca purtător de sens, în primă instanță.

\subsection{Limbajul articulat}

Fie că receptorul emiterii vocale a cuvântului este partenerul de scenă sau spectatorul, ,între vorbitor și ascultător e generat limbajul ${ }^{\text {"111 }}$. Astfel, prin rostire, cuvântul scris va

8. V. ibidem, p. 46.

9. Constantin Noica, Cuvânt împreună despre rostirea românească, București, Editura Eminescu, 1987, p. 25.

10. Ibidem, p. 26.

11. Paul Cobley, Câte ceva despre semiotică, traducere de Alexandra Olivotto, București, Editura Curtea veche, 2004, p. 167. 
deveni semn lingvistic vorbit și se va încadra în parametrii unui limbaj. Apartenența vorbirii de pe scenă la rigorile acestui sistem implică respectarea unor elemente definitorii, dar și de finețe ale acestuia, oferind exprimării verbale prospețime, originalitate, spontaneitate, vitalitate, calități specifice actului lingvistic originar. Actorul are sarcina de a descoase mecanismele de realizare și funcționare ale acestui limbaj pentru a le putea accesa în momentul creației și, totodată, pentru a surprinde substanța, subterfugiile procesului de elaborare a acestuia, chiar dacă actul vorbirii se învață încă din primii ani de existență prin imitare. De asemenea, după înscrierea în aria acestui sistem, cuvântul scris capătă o cu totul altă dimensiune decât cea a constrângerii în formă grafică deoarece „Limbajul spune totdeauna ceva în plus față de sensul lui literal, inaccesibil, care este deja pierdut încă de la începutul emiterii textuale ${ }^{\text {"12 }}$.

Utilizarea limbajului articulat își propune ca, printr-un sistem de semne, să exprime și să comunice sentimente sau conținuturi ale conștienței ${ }^{13}$. Astfel, cuvântul rostit dobândește o serie de esențe pe care trebuie să le expedieze atât prin formă, cât și prin conținut. Totodată, rostirea necesită o asumare și implicare interioară care să conducă spre o redare veridică a sunetului, a cuvântului, un sunet deținător de încărcătură, un cuvânt care să fie emis ca o manifestare a lumii lăuntrice.

Prin emiterea fiecărui sunet articulat, unitate de bază în formarea cuvântului ce se înscrie în procesul de vorbire, putem discuta de o apelare și aderare la cele două realități concrete ce fundamentează limbajul articulat uman, actul lingvistic și limba ${ }^{14}$. Această înscriere într-un sistem al vorbei rostite pe scenă implică o conștientizare din partea actorului în ceea ce privește conceptele și principiile de funcționare ale fiecărui act lingvistic, fiecare replică, prin pronunțare, devenind un act lingvistic.

12. Umberto Eco, Limitele interpretării, traducere de Ștefania Mincu și Daniela Crăciun, Iași, Editura Polirom, 2016, p. 6.

13. V. Eugenio Coseriu, Introducere in lingvistică, ed. cit. p. 17.

14. Ibidem. 


\subsection{Actul lingvistic}

În altă ordine de idei, textul rostit de actor devine act lingvistic prin simpla rostire. Totodată, actorul are responsabilitatea de a trata fiecare replică ca pe un act lingvistic, drept un vehicul pentru a transmite și a comunica atât colegului de scenă, cât și spectatorului. Mai simplu spus, artistul trebuie să conștientizeze și să aprofundeze mecanismul de producere al acestor acte lingvistice, să creeze organic replica. Astfel, este imperios necesar un laborator lăuntric care permite emiterea cuvântului, actul lingvistic fiind unul unic, inedit și care manifestă o consimilitudine între intuiție și expresie tocmai prin caracterul său de act de creație ${ }^{15}$. Putem semnala aici apariția unei serii de parametri pe care trebuie să îi îndeplinească cuvântul rostit pe scenă și, de asemenea, o explicație pertinentă a faptului că o rostire a unui text bine memorat nu este suficientă și că aceasta nu poate reprezenta decât o plăcere auditivă.

Fiecare replică presupune astfel o geneză care să producă sunetul articulat și care să provoace o reacție partenerului de scenă, o declanșare în făptuirea replicii-răspuns. Concomitent, replica emițătorului va acționa și asupra spectatorului, provocând o procesare lăuntrică a bagajului sonor absorbit. Discutăm aici despre cei doi participanți esențiali în actul lingvistic, vorbitorul și ascultătorul. În acest sens, artistul-emițător are sarcina în cadrul fiecărui act lingvistic de a expune „o intuiție și o expresie“16 vizând „o percepere și o imagine (o nouă intuiție) ${ }^{\text {“17 }}$ din partea receptorului său, fie el direct sau indirect. Un exemplu elocvent în care actorul expediază prin sunet imagini vizuale este întâlnit cu preponderență în textele ce presupun ilustrarea unui tablou descriptiv, atunci când spectatorul trebuie să vizualizeze ceea ce $a$ văzut artistul, iar interpretul dramatic trebuie să-și imagineze și să redea ceea ce a conceput dramaturgul.

15. Ibidem, p. 26.

16. Ibidem, p. 30.

17. Ibidem, p. 30. 
$\mathrm{Nu}$ putem omite existența unor monologuri în cadrul reprezentației scenice, momente în care ne vorbim utilizând limba comunității, comunicând la fel ca atunci când transmitem unei alte persoane ${ }^{18}$. Această comunicare cu propria persoană pe scenă trebuie să confere același nivel de intimitate impus prin stilul specific, dar nu trebuie neglijată prezența receptorului, a publicului.

$\mathrm{Ca}$ ansamblu de sunete articulate și ca element al actului lingvistic, cuvântul rostit pe scenă aparține limbajului, ,un fenomen extrem de complex: prezintă aspecte pur fizice (sunetele) și aspecte fiziologice, aspecte psihice şi aspecte logice, aspecte individuale şi aspecte sociale“19. Astfel, dincolo de sonor și întregul proces fiziologic de formare a acestuia, vorba rostită de actor are responsabilitatea de a proveni dintr-un fundament psihic filtrat logic și încadrat social. Această delimitare între sunetul concret creat prin emiterea sa și conținutul său psihic și logic susține o dublă perspectivă a cuvântului, „,ca fapt fonic și ca fapt semnificativ“20. Totodată, actorul nu poate pierde din vedere considerentul „esenței de rostire-numire a lucrurilor" ${ }^{\text {"21 }}$, de a atribui sonorității un conținut, o semnificație, o trimitere.

\subsection{Cuvântul-semn}

Înaintând cuvântul ca formațiune a limbajului în vederea comunicării, acesta poate fi considerat semn care „servește la redarea unei idei, a unui concept sau a unui sentiment, cu care semnul însuși nu coincide ${ }^{\text {“222 }}$. Astfel, actorul nu jonglează doar cu sunete, ci cu semne care ilustrează în laboratorul de percepere al ascultătorului imagini. Totodată, semnul lingvistic are capacitatea de reprezentare, acea valență

18. Ibidem, p. 29.

19. Ibidem, p. 48.

20. Ibidem, p. 61.

21. Angelo Morretta, Cuvântul și tăcerea, traducere de Mara și Florin Chirițescu, București, Editura Tehnică, 1994, p. 67.

22. Eugenio Coseriu, Introducere în lingvistică, ed. cit., p. 21. 
simbolică, ,valoare care nu rezidă în semnele materiale ca atare, valoare la care acestea doar se referă“'23. Învelișul sonor necesită din partea actorului o anumită claritate, o precizie a semnului transmis. Un simplu accent tonic schimbat poate schimba întreaga semnificație a cuvântului care poate degenera întreaga propoziție, frază și chiar mesajul în întregime.

Privind cuvântul dincolo de o emisiune vocală, artistul capătă o altă viziune asupra propriului instrument de exprimare, înțelegând că el operează de fapt cu semne. Pe de o parte, acesta poate fi ",constituit din semnificat («obiect»-al-semnului) și semnificant (nume-al-obiectului)“ ${ }^{24}$. Această componență trebuie să fie susținută de actor printr-un echilibru între formă și conținut, tratând cu seriozitate fiecare semn lingvistic scris din textul dramatic pentru a putea trimite cu exactitate spre ceea ce a fost codat din scriitură. Artistul nu poate acționa cu semne a căror semnificație nu îi este cunoscută sau este incertă, adăugând aici exercițiul necesar de decodare a textului scris pentru a-l putea coda și reda sonor. Altfel spus, pentru a aprofunda această capacitate de a întruchipa prin cuvântul rostit, putem socoti ,drept semn tot ceea ce, pe baza unei convenții sociale acceptate dinainte, poate fi înțeles ca ceva ce ține locul la altceva“ ${ }^{25}$. Putem consemna, de asemenea, aici importanța formei sonore a cuvântului care, prin intermediul vocii și a calităților acesteia, va reuși să redea cât mai fidel conceptul sau obiectul la care se face trimiterea, acea aparență care să redea impecabil esența. Pe de altă parte, Ferdinand de Saussure identifică o lipsă de relaționare între învelișul sonor și cel conceptual în sine și, totodată, o legătură între semnificat și semnificant în ideea în care cel dintâi component al semnului 1-a implementat pe cel de-al doilea ${ }^{26}$, semnificatul neputând fi desemnat în lipsa semnificantului.

23. Ibidem, p. 23.

24. Paul Schveiger, O introducere în semiotică, București, Editura Științifică și enciclopedică, 1984, p. 28.

25. Umberto Eco, Tratat de semiotică generală, traducere de Anca Giurescu și Cezar Radu, Editura științifică și enciclopedică, București, 1982, p. 28.

26. Emil Ionescu, Manual de lingvistică generală, București, Editura 


\subsection{Semnul lingvistic - o dublă perspectivă}

În perspectiva lui Patrice Pavis, care pornește tot de la viziunea impusă de Saussure, semnul lingvistic devine semn teatral, dar care, spre deosebire de celelalte semne scenice, nu presupune o analogie între semnificant și semnificat, acesta fiind lipsit de acea motivare a sensului ${ }^{27}$. Prin apartenența sa la limbaj, cuvântul rostit, semnul, capătă o coordonată psihică, discutându-se despre existența unei realități mentale și producerea semnului prin rostire. Se distinge o discrepanță între cele două, fiecare desemnând două abordări ale conceptului de semn ${ }^{28}$. Aspectul de realitate mentală poate fi un reper fundamental în realizarea actului lingvistic de către actor, subliniind o dublă existență a acestei realități care poate susține eficient laboratorul de creație. În primă instanță, în procesul de descifrare a textului dramatic, artistul trebuie să depisteze, să intuiască acea realitate mentală care a dus la producerea cuvântului scris. Astfel, el se va putea apropria de intențiile dramaturgului și de sensurile profunde ascunse dincolo de litere. Mai mult decât atât, în dorința de a emite un text purtător de însemnătate și înțelesuri, el trebuie să urmărească dezvoltarea acelei capacități de asumare a realității psihice care să determine rostirea cuvântului. Ideea de contur sonor care vine pe baza unui fundament psihic susține semnul ca fiind unul psiho-fizic ${ }^{29}$. Am putea discuta chiar despre o a treia abordare a realității psihice dacă o considerăm drept una distinctă pe cea pe care actorul o construiește odată cu crearea personajului. Astfel, interpretul dramatic trebuie să manifeste un interes față de semnul lingvistic, fie el grafic sau verbal, pentru a putea, pe de o parte, decoda, iar pe de altă parte, transmite cu siguranță și cu capacitatea de a preconiza efectul și percepere fiecărei emisii vocale.

Bic All, 2001, p. 69.

27. Patrice Pavis, Dictionaire du théâtre, Paris, Dunod Éditeur, 2019, p. 501.

28. Emil Ionescu, Manual de lingvistică generală, ed. cit., p. 72.

29. Ibidem. 


\subsection{Perspectiva psihologică}

În încercarea de a produce un cuvânt care să se identifice cu cel specific limbajului uman articulat și cu rolul expedierii acestuia, înainte de a discuta particularitățile vorbirii scenice, aducem în discuție perspectiva psihologică care generează unele clarificări asupra procesului intern care conduce la o realizare sonoră deținătoare de semnificație. $\mathrm{Cu}$ preponderență, behavioriștii au lansat viziunea în care semnele, și anume cuvintele, sunt potrivite unor stimuli cărora li se atribuie o serie de reacții sub forma unor imagini ${ }^{30}$. Așadar, cuvântul rostit are sarcina de a activa, de a stârni precum un stimul și de a genera în mintea receptorului, fie partener de scenă, fie spectator, imagini, trimiteri. Totodată, există un consens între modelul comunicării lingvistice și această abordare psihologică, această relație stimul-reacție fiind una de tip cauză-efect, iar fiecare reacție provoacă noi stimuli, fie de natură lingvistică, fie sub forma unei acțiuni. Un alt aspect esențial care fundamentează acest concept, este prezența unui context pe care am putea să îl asemănăm cu situația scenică dată ${ }^{31}$. Pe baza aceleiași relații de cauzalitate, în propriul laborator de creație, actorul ar putea privi cuvântul rostit ca pe o reacție și ar putea să încerce să determine cauza, acea cerință interioară care duce la exprimare. Astfel, cuvântul poate stimula și poate depăși prin rostire nivelul de reproducere a unui text bine memorat. Lipsa acestei cauze lăuntrice, una preponderent de natură psihică, va susține doar un fond sonor fad și lipsit de expresie.

\subsection{Limbajul și cunoașterea}

În altă ordine de idei, Benedetto Croce îndreaptă atenția spre o formă expresivă la care se ajunge atunci când este manifestată intuiția, acesta considerând că fiecare intuiție se produce prin expresie. De asemenea, el propune două tipuri de cunoaștere pe care le folosește în definirea limbajului:

30. Eugenio Coseriu, Introducere în lingvistică, ed. cit., pp. 21-22.

31. V. Emil Ionescu, Manual de lingvistică generală, ed. cit., p. 101. 
cunoașterea intuitivă și cunoașterea logică. Cea din urmă are ca nucleu adevărul, iar în ceea ce reprezintă intuiția filosoful surprinde concomitent senzoralitatea, emoționalitatea și imaginația ${ }^{32}$. Altfel spus, aceste două tipuri de cunoaștere conduc spre o formă consistentă expresiv și, totodată, putem considera elementele prin care acestea sunt susținute drept fundamentale în crearea expresiilor pe scenă de către actor, esențe care guvernează o exprimare plastică și veridică.

În continuarea acestui concept de dublă cunoaștere, nu putem să nu luăm în considerare dimensiunea dată cuvântului la antici prin care, depășind ideea de instrument în comunicare, individul ,se reconecta la fenomenele primordiale ale existenței și ale absolutului. Viața era un miracol și vocea, care dădea viață obiectelor și ființelor prin cuvinte, nu era mai puțin marele mister care transcende realitatea vizibilului““33. Astfel, vocea trece dincolo de nivelul perceptibil al vizibilului și, totodată, prin sunetul articulat asamblat în cuvânt transmite imagini, un transfer sonor invizibil care generează vizibilul. Conexiunea cu primordialitatea existenței și a absolutului poate fi susținută de Cuvântul originar, esențial. Racordând fiecare cuvânt rostit la nivelul acestuia și dorind regăsirea unui rost în ideea de rost al lumii, Constantin Noica susține că cea dintâi a fost Rostirea ${ }^{34}$.

\subsection{Mecanismele actului lingvistic}

Ansamblul de caracteristici susținute în elaborarea cuvântului ca semn lingvistic trebuie surprins în elaborarea actului lingvistic din care face parte. În conturarea acelui mod de elaborare și organizare a fiecărui act lingvistic întâlnit pe scenă, artistul dramatic are datoria de a lua în considerare complexitatea proceselor implicate în realizarea actului lingvistic. Forma fonică este executată de fenomenul fizic și fiziologic, acțiunea psihică care include producerea, perceperea

32. Ibidem, pp. 55-57.

33. Angelo Morreta, Cuvântul și tăcerea, ed. cit., pp. 66-67.

34, V. Constantin Noica, Cuvânt împreună despre rostirea românească, ed. cit., p. 20. 
și utilizarea semnelor este concepută de fenomenul psihic, iar implicarea unui proces logic, rațional, care conduce spre cunoaștere și care operează cu semnele ca simboluri este asigurată de fenomenul intelectual sau rațional ${ }^{35}$. Așadar, cuvântul scris memorat trebuie asumat și înglobat ca simbol, trebuie procesat, gândit înainte de a fi emis prin punerea în mișcare a aparatelor fiziologice necesare, practic declanșarea conștientă a unui mecanism uzat în vorbirea cotidiană a actorului.

Încărcătura și natura psihică specifică limbajului lipsită de valențe emotive conferă acestuia calitatea de limbaj enunțiativ. La polul opus, se situează limbajul emotiv care implică și partea afectivă, depășind prin culoarea emotivă nivelul de simplă enunțare și comunicare ${ }^{36}$. Vorbirea actorului trebuie să depășească nivelul de simplă enunțare, pentru că dincolo de ideile pe care le transmite prin nucleul cognitiv de realizare a acestora, el tinde spre transmiterea unei emoții și astfel el apelează și la filonul sensibilității pentru a comunica replici care stimulează atât psihicul spectatorului, cât și sufletul acestuia prin emiterea unui sunet articulat impecabil și frumos din punct de vedere acustic.

\subsection{Limba - totalitatea actelor lingvistice}

Cea de-a doua componentă fundamentală a limbajului este limba, care poate fi considerată drept totalitate a actelor lingvistice, o înglobare a acestora. Fiind un organism viu și având sursa în actele lingvistice, actorul nu trebuie să permită emiterea unor forme lingvistice greșite, atât gramatical, cât și fonic, având sarcina de a sluji în menținerea și expunerea limbii române literare, punându-se în temă cu posibilele reglementări și îngrijindu-se de accentul tonic corespunzător fiecărui cuvânt și de învelișul sonor corect pronunțat. Schimbările pe care le suportă limba continuu susțin ca „lucru normal necoincidența între expresie și înțelegere și între creație

35. V. Eugenio Coseriu, Introducere în lingvistică, ed. cit., p. 92.

36. Ibidem, p. 54. 
și modelul pe care aceasta îl implică“37. În altă ordine de idei: „Prin cultivarea limbii înțeleg grija deosebită ce trebuie să avem pentru folosirea corectă a limbii, adică pentru respectarea normelor fonetice, lexicale și gramaticale, căci numai astfel se poate realiza o comunicare fidelă a gândurilor și sentimentelor vorbitorului “38. Așadar, preocuparea actorului nu trebuie să se oprească doar la nivel fonic, ținând cont și de rigorile impuse de gramatică și vocabular.

Orice distorsionare a emiterii fonice a cuvântului diferită de cea considerată literară se poate încadra în vorbirea scenică a interpretului în concordanță cu personajul creat fie pentru a se încadra în filonul comic, fie pentru a scoate în evidență proveniența sau anumite nuanțe care caracterizează noul individ creat. Aceste culori în nuanțarea vorbirii se pot încadra tot în seria semnelor care trebuie descifrate, procesate și asumate organic de către interpret pentru a nu rămâne la stadiul de simplă formă. Totodată, nu trebuie omisă „o anumită potrivire între concept și imagine acustică“39.

\subsection{Dialog/Discuție}

Schimbul de replici, de acte lingvistice, poate fi considerat sub formă de dialog care poate căpăta titulatura de conversație sau de discuție, în funcție de cerințele situației dramatice. Cele două concepte se pot defini prin comparație, discuția fiind cea care impune un mediu instituționalizat. În cadrul conversației cei părtași în actul comunicării sunt vizați ca simpli indivizi, pe când în spectrul discuției întâlnim manifestarea unor atribuții sociale. În ceea ce privește tematica abordată, discuția prezintă rigiditate prin prisma atmosferei instituționalizate, pe când conversația nu prezintă constrângeri. Realizarea conversației are la bază interacțiunea creată între participanți, dar

37. Eugenio Coseriu, Introducere în lingvistică, ed. cit., p. 77.

38. Mircea Zdrenghea, Studii lingvistice, Alba Iulia / Cluj-Napoca, Editura Altip /Editura Scriptor, 2014, p. 355.

39. Ion Coja, „Cuvântul e semn?“ în Lucia Wald (coord.), Semantică și semiotică, București, Editura științifică și enciclopedică, 1981, p. 101. 40. V. Liliana Ionescu-Ruxăndroiu, Conversația: structuri și strategii: 
și acțiunea. ${ }^{40}$ Diferențierea celor două forme de comunicare și înscrierea textului într-una din cele două categorii pot ajuta artistul dramatic în modul de livrare a replicilor, conferind vorbirii autenticitate. Totodată, frazele învățate trebuie să depășească nivelul de simplă emitere, ajungând la livrarea replicii ca un fapt prin care se acționează și, de asemenea, ca rezultat al unei interacțiuni între partenerii prezenți la actul lingvistic.

\subsection{Cuvânt - limbaj-comunicare}

Compus dintr-un sonor corect articulat și vehiculând semnificație, cuvântul rostit trebuie să dobândească calitatea primordială, inteligibilitatea, ,condiția primă și indisponibilă a limbajului “41. Aceasta va conduce spre scopul fundamental al exprimării, înțelegerea, care poate fi definită ca „finalitatea însăși a vorbirii““42. Premergătoare acestei înțelegeri este perceperea, care susține încărcătura interioară imperios necesară rostirii și ,acționată la rândul său de complexul suflet-spirit“43. În vederea consolidării acestui raport percepere-înțelegere, sunt identificate trei modele care demonstrează modul de funcționare a înțelegerii și care pot fi utilizate atât în modul de descifrare a textului scris, cât și în modul de procesare a replicilor primite de la partenerul de scenă și, totodată, din ipostaza și perspectiva receptorului elementar, spectatorul. Modelul bottom-up propune înțelegerea pornind de la perceperea sunetului articulat care prin alcătuire implică perceperea textului în totalitate. Modelul top-down implică reversul celui de dinainte, plecând de la text spre unitatea de bază care îl alcătuiește. Al treilea model intitulat compensatoriu interactiv susține o înțelegere în care se accesează sub forma unui proces interactiv date din ierarhii diferite ${ }^{44}$.

sugestii pentru o pragmatică a românei vorbite, București, Editura All Educational, 1999, p. 39.

41. Eugenio Coseriu, Introducere în lingvistică, ed. cit., p. 54.

42. Ibidem, p. 29.

43. Angelo Moretta, Cuvântul și tăcerea, ed. cit., p. 68.

44. V. Mariana Pitar, Textul injonctiv: repere teoretice, Timișoara, Editura Excelsior Art, 2007, p. 37. 
Călătoria cuvântului de la percepția vizuală a logosului scris la percepția auditivă trimisă către receptor se încheie în momentul înfăptuirii comunicării, aceasta reprezentând, de fapt, „finalitatea limbajului““45. Elaborarea lăuntrică a instrumentului trebuie să se înscrie în particularitățile comunicării verbale care se creează sub ochii noștri și implică o componentă empatică și participativă ${ }^{46}$. Astfel, semnul lingvistic reprezentat grafic se desprinde din comunicarea scrisă și devine parte integrată în comunicarea orală, un bagaj fonic și filtrat lăuntric care se rostogolește de pe scenă și pătrunde spectatorul, invadându-i natura lăuntrică, nu înainte de a produce o plăcere auditivă. Totodată, prin rostire, litera capătă prin sunet esență și valențe cu capacitate de transmitere deoarece „Doar vorbirea poate arăta coloratura afectivă a sunetelor, cuvintelor și a construcțiilor, a propozițiilor “477, o vorbire a artistului care va manifesta cuvinte purtătoare de sens și consistență afectivă.

\section{Cuvântul „celuilalt“ - a fi-a vorbi}

\subsection{Noțiuni introductive}

În căutarea acelui cuvânt rostit pe scenă prin care să se transmită idei și emoții, se poate decupa un parcurs al cuvântului scris care devine o întruchipare a gândului și a trăirii prin interiorizare. Astfel, se poate distinge un traseu prin care forma sonoră capătă o componentă rațională și una emotivă, un cuvânt viu care depășește nivelul de plăcere auditivă și acționează asupra universului lăuntric al spectatorului. Eficiența acestui drum realizat de actor pentru emiterea cuvântului organic poate fi evaluată în gradul de empatie atins prin receptarea acestuia. Această rezonanță empatică a spectatorului depinde de nivelul „retrăirii““48 actorului și,

45. Eugenio Coseriu, Introducere în lingvistică, ed. cit., p. 18.

46. Liliana Ionescu-Ruxăndroiu, Conversația, ed. cit., p. 19.

47. Emil Ionescu, Manual de lingvistică generală, ed. cit., p. 201.

48. Stroe Marcus, Empatie și personalitate, București, Editura Atos, 1997, p. 16. 
totodată, de abilitatea de a empatiza a spectatorului, situând această trăsătură în raportul dintre înnăscut și dobândit, relația dintre capacitate și comportament“ 49 .

Privind această modalitate sub forma unei metode de generare a unui instrument verbal care transmite idei și emoții, se percep, totuși, diferențe între asumarea lăuntrică, exteriorizare și receptare. Aceste discrepanțe între forjarea lăuntrică și exprimarea acesteia prin verbalizarea cuvântului memorat se manifestă, de fapt, ca discordanțe între codare și decodare. Putem să ne raportăm la acest blocaj în procesul de creație, bazându-ne pe relația cauză-efect. Astfel, cuvântul rostit poate fi considerat drept efect, iar cauza, una de natură interioară. Sursa acestei distorsionări interiorizare-exteriorizare poate fi identificată ca fiind actorul prin lipsa preciziei între ceea ce codează în laboratorul său intrinsec și se decodează prin prisma elementului de expresie. Altfel spus, cuvântul reușește să fie unul viu, care are capacitatea de a transmite, dar este privat de aprobarea celorlalte instrumente de expresie implicate în procesul de comunicare. Această lipsă de asociere a elementelor de expresivitate conduce spre o comunicare ineficientă, elementul verbal fiind dărâmat de un simplu element nonverbal. Totodată, lipsa unei coordonări între acestea poate debusola atât partenerul de scenă, cât și spectatorul.

Elementele de expresie utilizate de actor sunt cele specifice tipului de comunicare directă aflându-se în ,situația în care mesajul este transmis uzitându-se mijloace primare cuvânt, gest, mimică“50. Odată rostite, cuvintele alcătuiesc mesajul verbal și se pot decupa cele două tipuri de comunicare, verbală și nonverbală, iar „Ansamblul elementelor nonverbale - mimică, privire, gesturi, postură etc. întreține conversația și dă semnificație mesajului verbal“"51. „În altă

49. Ibidem, p. 10.

50. Irina Stănciugelu, Raluca Tudor, Adriana Tran, Vasile Tran, Teoria comunicării, Bucureşti, Editura Tritonic, 2014, p. 40.

51. Septimiu Chelcea, Loredana Ivan, Adina Chelcea, Comunicarea nonverbală: gesturile şi postura. Cuvintele nu sunt de-ajuns, Bucureşti, Editura Comunicare.ro, 2008, p. 35. 
ordine de idei, se explică susținerea componentei verbale din partea celorlalte instrumente prin ponderea pe care o ocupă în fenomenul comunicării. Dincolo de mitul 55-38-7, 55 la sută prin limbajul corporal, 38 la sută prin paralimbaj și abia 7 la sută prin limbajul verbal“52, cele două tipuri de elemente cooperează, deoarece „limbajul nonverbal și limbajul verbal operează împreună, se sprijină reciproc în procesul comunicării““53. Astfel, „cuvântul rostit are nevoie de o armonizare cu celelalte elemente pentru a transmite cu precizie, luând în considerare faptul că acesta doar îmbracă ceea ce dorim să comunicăm" ${ }^{\text {"54. }}$.

Sursa originară a cuvântului rămâne, însă, textul dramatic asupra căruia vom propune o perspectivă mai detaliată de decodare și, mai apoi, de codare, raportându-ne la acesta ca prim mijloc care îi stimulează actorului empatia.

Tratarea textului doar ca formă va conduce la o simplă aparență sonoră a cuvântului. Forjarea, căutarea dincolo de această adunare de litere conduce spre decodarea originară care a fost probată și validată de dramaturg prin empatie cu propria creație. Se poate discuta în cazul scriitorului de o dublă formă de a empatiza, atât în elaborarea creației, cât și din perspectivă detașată, din cea a receptării dinafară a operei, două moduri prin care scriitorul empatizează atât cu propriile personaje prin transfer psihologic în psihologia acestora, cât și cu cititorul prin prisma imaginației ${ }^{55}$. Nivelul optim de contopire prin empatie este surprins în exemplul scriitorului Gustave Flaubert, care atunci când scria despre otrăvirea Emmei Bovary avea atât de insistent gustul de arsenic în gură, încât acesta s-a manifestat sub forma a două indigestii ${ }^{56}$. Această codare atât de autentică trebuie descoperită în toată complexitatea și profunzimea ei, astfel încât

52. Ibidem, p. 37.

53. Ibidem, p. 37.

54. Irina Stănciugelu, Raluca Tudor, Adriana Tran, Vasile Tran, Teoria comunicării, ed. cit., p. 156.

55. V. Stroe Marcus, Empatie și personalitate, ed. cit., p. 163

56. V. ibidem, p. 163. 
prin re-codarea actorului să se ajungă la o descifrare cât mai aproape de cea originară. Paternitatea aceasta a textului ca sursă a esențelor poate reprezenta o fundamentare în căutările artistului dramatic, considerând opera dramatică, atât la nivel micro, cuvânt, replică, scenă, cât și la nivel macro, o formă care a rezultat în urma unui laborator de codare a unui conținut și a unui circuit de creație.

În altă ordine de idei, cuvântul scris poate fi considerat un nucleu în căutarea și completarea elementelor de expresie atât de natură vocală, cât și nonverbală, acestea însumând „două moduri de reprezentare distincte, dar [care] au aceeași coordonare ${ }^{\text {“57 }}$. Astfel, lipsa identității între codarea și decodarea cuvântului organic prezintă o problemă de ordin interior, care conduce la revizuirea și extinderea acelui laborator lăuntric al interpretului dramatic, mai exact, la cunoașterea și consolidarea acelui generator interior care ghidează și conduce instrumentele expresive.

Angajarea tuturor mijloacelor de exprimare în ,orice proces de comunicare are o triplă dimensiune: comunicarea exteriorizată (acțiunile verbale și nonverbale observabile de către interlocutori), metacomunicarea (ceea ce se înțelege dincolo de cuvinte) și intracomunicarea (comunicarea realizată de fiecare individ în forul său interior, la nivelul sinelui) “58.

Prin rostire, cuvântul devine formă de exprimare verbală orală și exteriorizează acel conținut informațional (CE?). Pentru a desluși partea de metacomunicare care poate însuma codarea lăuntrică sau ceea ce nu spune personajul, actorul poate empatiza cu scriitura astfel încât să reușească să transmită emoția dorită (CUM?). Din ceea CE spune personajul și CUM transmite se poate ajunge spre CINE?, folosind cuvântul dramaturgului ca o metodă de caracterizare indirectă a personajului.

57. Apud Septimiu Chelcea, Loredana Ivan, Adina Chelcea, Comunicarea nonverbală, ed. cit., p. 37.

58. Irina Stănciugelu, Raluca Tudor, Adriana Tran, Vasile Tran, Teoria comunicării, ed. cit., p. 37. 
Empatia rămâne o modalitate în creionarea și crearea personajului dramatic, reprezentând „transpunerea psihologică a eului în psihologia celuilalt“59. Putem considera această definiție-cheie o descriere succintă a procesului creator actoricesc. Astfel, cu ajutorul acesteia, vom porni în căutarea personajului și, de asemenea, a vorbirii acestuia.

$\mathrm{Cu}$ alte cuvinte, așa cum am remarcat mai sus, cuvântul viu nu reușește să devină eficient atunci când privim cuvântul alături de celelalte instrumente de expresie. Încadrându-1 în procesul comunicațional, el însumează mesajul verbal care „are un caracter ireversibil ${ }^{\text {“60 }}$. Odată rostit, instrumentul verbal nu mai poate fi modificat. Ca logosul rostit să capete forță, iar mesajul însumat de acesta să capete veridicitate și siguranță este imperios necesară „o convergență între mesajul verbal și elementele nonverbale, impactul mesajului este mai puternic" ${ }^{\text {"61 }}$. Așadar, cuvântul are nevoie în transmitere de o susținere din partea instrumentelor de comunicare nonverbală. Mai mult decât atât, mesajul are o componentă a unui conținut manifest și o componentă a mesajului latent, cel din urmă având un grad mai ridicat de semnificație deseori $^{62}$. Conținutul manifest este însumat de aspectul verbalizat, iar partea latentă ține de componenta nonverbală. Vom urmări, astfel, cum reușește componentă nonverbală să valideze cuvântul, așa încât acesta să depășească nivelul de simplă pronunție, căutând să fundamentăm cauzele interioare generatoare, dobândind acel instrument verbal care transmite cu precizie și este animat armonios de celelalte forme de expresie, un cuvânt care trimite spre receptor un bagaj informațional prin sincronizarea părții de conținut cu cea a expresiei. Acest echilibru între elementele implicate în fenomenul de comunicare prin validare este specific, nu

59. Stroe Marcus, Empatie și personalitate, ed. cit., p. 11.

60. Irina Stănciugelu, Raluca Tudor, Adriana Tran, Vasile Tran, Teoria comunicării, ed. cit., p. 38.

61. Loredana Ivan, Cele mai importante 20 de secunde in comunicarea nonverbală, Bucureşti, Editura Tritonic, 2009, p. 93.

62. Irina Stănciugelu, Raluca Tudor, Adriana Tran, Vasile Tran, Teoria comunicării, ed. cit., p. 38. 
are legătură cu anularea acestora între ele prin expresia utilizată în teatru și amintită în capitolul anterior, semn pe semn. Aici putem aminti acele gesturi de ilustrare ${ }^{63}$ care alterează mesajul. Discutăm despre o echivalare care ajută ca rostirea să depășească zona abordată în vorbirea curentă, trecând dincolo de nivelul de vorbă, de ansamblu de sunete care nu reușesc de fiecare dată pe deplin să comunice. În ceea ce privește cuvântul uzitat în comedie, putem remarca o discrepanță între armele expresive care provoacă amuzamentul spectatorului, deoarece „O bună parte din umor se bazează pe nepotrivirea dintre expresie și conținut “64.

Instrumentele nonverbale devin relevante în procesul comunicării prin atribuțiile pe care le îndeplinesc alături de componenta verbală. Cu ajutorul acestora se obține: ,a) exprimarea emoțiilor; b) transmiterea atitudinilor interpersonale (dominanță/supunere, plăcere/neplăcere etc.); c) prezentarea personalității; d) acompanierea vorbirii, ca feedback, pentru a atrage atenția“65. Remarcăm astfel că prin aceste elemente care însoțesc și coexistă alături de cuvântul care bate aerul se transmit valențe despre universul interior al individului, aspecte despre emițător pe care le află receptorul și care, adeseori, alterează cuprinsul informațional și sensul sunetului articulat. Altfel spus, trupul și vocea sunt cele care, prin importanța lor în întregul fenomen, aprobă și animă ceea ce transmit elementele verbale.

Începuturile comunicării verbale au fost declanșate de valențe nonverbale, deoarece „limbajul uman își are originea în exprimarea sonoră a emoțiilor, ca o formă de comunicare nonverbală“"66, în consecință, vocea e cea care fundamentează cuvântul și reprezintă un punct de reper în confirmarea acestuia.

63. Septimiu Chelcea, Loredana Ivan, Adina Chelcea, Comunicarea nonverbală, ed. cit., p. 44.

64. Matthew McKay, Martha Davis, Patrick Fanning, Mesaje: ghid practic pentru dezvoltarea abilităţilor de comunicare, traducere de Adriana Orban, București, Editura All, 2016.

65. Ibidem, p. 43.

66. Septimiu Chelcea, Loredana Ivan, Adina Chelcea, Comunicarea nonverbală, ed. cit., p. 31 . 
În lucrul cu studenții de la actorie la disciplinele Tehnica vorbirii sau Vorbire scenică, se identifică discrepanțe între ceea ce aceștia spun și felul cum spun. Se observă diferențe între culoarea vocală și cuvântul rostit. Acest fapt ne invită la dezvoltarea acestui laborator interior de creație care să confere susținerea necesară constituentului verbal.

Aminteam mai sus ideea de căutare a modulului de a vorbi al personajului concomitent cu traseul de construire a personajului. Influența elementelor nonverbale și greutatea funcțiilor pe care le îndeplinesc trimit spre întrebarea: Cine, de fapt, este implicat în procesul de comunicare? Actorul sau personajul? Sau actorul prin prisma noii identități? Acest concept de nouă identitate este adus în discuție prin prisma faptului că, prin comunicare, se transmit elemente despre personalitate, mai exact, despre Cine este individul care inițiază exprimarea. În aprofundarea acestor idei, comunicarea introduce în cadrul procesului său noțiunea de „propria identitate“67 și, totodată, de „proiectarea selfului." 68

Toate elementele implicate în fenomenul de transmitere sunt gestionate de aceeași sursă generatoare care pune în mișcare aceste tipuri diferite de expresie. Cum reușim să ajungem, altfel spus, la modul specific de a comunica sub amprenta unei noi identități, dincolo de aparență? Această întrebare este valabilă și în cazul în care avem un singur actor și mai multe personaje cărora le căutăm felul de a vorbi și, mai mult decât atât, de a comunica fără a apela la o formă care va transmite incontrolabil informații din forul intrinsec al actorului și nu al acestui celălalt. „Adevăratul romancier nu-și domină romanul, ci devine propriul său roman, se confundă într-însul" ${ }^{\text {"69 }}$. Ideea aceasta de confundare ne interesează în procesul comunicațional, privindu-l pe acesta dincolo de

67. Irina Stănciugelu, Raluca Tudor, Adriana Tran, Vasile Tran, Teoria comunicării, ed. cit., p. 45.

68. Septimiu Chelcea, Loredana Ivan, Adina Chelcea, Comunicarea nonverbală, ed. cit., p. 45.

69. Apud Stroe Marcus, Empatie și personalitate, ed. cit., p. 161. 
partea sa de exteriorizare conștientă, o îndepărtare de Sine și o apropiere de personaj nu doar prin căutarea unei noi întruchipări. Diametral opus acestei abordări ca formă, se identifică fenomenul „identificării, eul se topește în celălalt, devine celălalt, pierzându-și propria identitate, fiind socotit un model de alienare empatică ${ }^{\text {" } 70}$. Pentru a se putea contopi cu acest celălalt, interpretul dramatic trebuie să îl definească, să îl descopere, ținând cont, de asemenea, de indicații și întreaga viziune regizorală.

Bazându-se pe „fenomenul imaginației substitutive“71 care definește literalmente procesualitatea conceptului de empatie, actorul intră în contact, inițial, cu textul dramatic, mai exact cu acele cuvinte scrise care pot fi considerate forme de exprimare scrisă a personajului care urmează a fi interpretat. Înainte de a introduce întreg ansamblul de elemente nonverbale, intervine chiar de la prima lectură partea vocală, aceea componentă paraverbală prin intermediul căreia se livrează date de ordin interior, mai exact, despre starea de spirit și despre cine este cel care comunică. Așadar, vocea poate fi privită și ca un fond care transmite și prin care urmează să se materializeze cuvântul, dar și ca un instrument de exteriorizare a unui bagaj lăuntric care însumează o serie de informații ce se pot afla în dezacord cu mesajul verbal.

Cu toate că vocea și cuvintele funcționează împreună, tendința este de a fi „mai atenți la cuvinte“72, existând pentru fiecare instrument de expresie un centru diferit de percepere și receptare. Componenta verbală a comunicării se adresează „aproape în exclusivitate minții care gândește. Sensul denotativ al cuvintelor este procesat digital, la rece, la nivelul cortexului cerebral. Doar unele sensuri conotative și semnificații abisale ale cuvintelor pot angaja senzorial și emoțional alte zone din creier"73. În ceea ce privește elementele nonverbale,

70. Ibidem, p. 22.

71. Ibidem, p. 162.

72. Ştefan Prutianu, Antrenamentul abilităţilor de comunicare, Editura Polirom, Iaşi, 2004, p. 30.

73. Ibidem, p. 30. 
voce și trup, „sunt adresate preponderent minții care simte și par a fi procesate la nivelul unor formațiuni mai primitive, mai reptiliene sau cel mult precorticale ale creierului ${ }^{\text {"77 }}$. Astfel, vorbirea de pe scenă, cuvintele și vocea ca materie primă care le fundamentează își propun să apeleze ambele moduri de decodare.

Dincolo de tendința de a ne îndrepta atenția spre conținutul verbal, ,așezând cuvântul la temelia condiției umane“75, se poate consemna necesitatea imperioasă a unui echilibru între mesajul vocalic și mesajul verbal. Altfel spus, o susținere a cuvântului din perspectivă paraverbală, un conținut interior livrat de voce pentru a valida logosul rostit pe scenă. Pe această corespondență și armonie cuvânt-voce se bazează vorbirea personajului care poate fi privită dincolo de formă, deoarece „vorbirea este imaginea spiritului; cum este omul, așa este și felul său de a vorbi“"76. Astfel, vom urmări traseul cuvântului, de la cel originar, scris în textul dramatic, spre cel care definește prin rostire un mod al personajului de a vorbi și prin care se reflectă felul de a fi al acestuia. Vom creiona, așadar, laboratorul interior prin care cuvântul transmite conținut interior și nu doar informații.

\subsection{Vocea „celuilalt"}

Prin antrenament vocal, actorul dobândește o ușurință în a jongla cu elementele paraverbale care definesc vorbirea, căpătând un control asupra disponibilităților sale vocale. Acest control tehnic îi oferă posibilitatea de a-și adapta calitățile vocale unei tipologii sau unei stări, căutând o formă prin care se decodifică caracteristicile codate. Pentru a depăși acest nivel de aparență, este necesară o asumare interioară care să confere un adevăr lăuntric instrumentului de expresie, acea cauză interioară care determină instrumentul expresiv

74. Ibidem, p. 30.

75. Ibidem, p. 31.

76. Septimiu Chelcea, Loredana Ivan, Adina Chelcea, Comunicarea nonverbală, ed. cit., p. 90. 
ca un efect. Totodată, această codare interioară susține acea unică coordonare ca un nucleu ce declanșează organic punerea in mișcare a mijloacelor de exprimare. Depistarea și înrădăcinarea interioară a acestui a fi reprezentat și surprins exterior conduce, astfel, spre o voce care devine o oglindă a interiorului personajului, a acelei noi identități.

Privind empatia ca un mecanism folosit în procesul de decodare și receptare, notăm faptul că aceasta „depinde în mare măsură de abilitatea de a interpreta comportamentul expresiv al altuia“"77. Actorul pornește în căutarea caracteristicilor personajului de la cuvântul scris, descifrând o tipologie cu ajutorul conexiunilor de tip ca și cum, găsind acel recognoscibil care conduce spre un stil specific noii identități. Fiecare nouă identitate, fiecare nou personaj se încadrează într-o tipologie umană și prezintă un comportament uman. Identificarea personalității și înscrierea personajului într-un tip de personalitate îi oferă actorului o pistă generoasă în abordarea noii provocări scenice, o perspectivă spre acea mobilare interioară autentică și veridică. Astfel, vocea reușește să devină un mijloc indirect de caracterizare a personajului, încadrarea personajului într-un tipar uman depășind nivelul de întruchipare prin fundamentarea lăuntrică a unor elemente specifice identității respective care se vor reflecta prin forma generată organic. Conturat astfel, personajul este pregătit pentru a se identifica cu el însuși, personajul. Din ceea ce spune personajul și modul în care spune reușim să găsim acel cine și felul de a fi, analizând, desigur, situațiile, relațiile, motivația.

Trecând peste nivelul de a da o culoare vocală nefiltrată interior, vocea apare ca o consecință a unor însușiri umane înmagazinate lăuntric, menținând acel echilibru între reprezentare și coordonare, între disponibilități probate și șlefuite tehnic și acoperirea și asumarea care să susțină expresia. În acest mod, se transmite către receptor un mesaj vocalic care devine un nucleu ce dezvăluie dedesubturi despre Sinele personajului care vorbește și se dobândește o voce care poate fi privită ca o suită de conținuturi și la care ajungem ca o formă de exteriorizare ce se creează viu, pe baza unui mecanism și nu doar pe baza

77. Apud Stroe Marcus, Empatie și personalitate, ed. cit., p. 14. 
imitării. Totodată, această ghidare interioară coordonează și generează unitar și elementele metalingvistice, râs, plâns, tuse, oftat, strănutat etc., care țin tot de registrul paraverbal al comunicării, venind în completarea vorbelor și comunicând despre specificul personajului, mai exact, al tipologiei umane în care acesta se încadrează. Astfel, vocea, prin elementele sale specifice, reușește să codeze personalitatea, tipologia, dincolo de o formă și devine o reflectare a unui laborator de codare și asumare, o expresie firească a unor caracteristici umane descifrate și aprofundate.

\subsection{Cuvântul viu - emoțiile „celuilat“}

Căutând acel transfer psihologic specific fenomenului de empatie, nu putem să nu precizăm componentele acesteia reprezentate de „factura bimodală, ce implică o combinare între viziunea cognitivă și cea afectivă“"78. În consecință, se poate consemna o altă susținere a cuvântului din perspectivă vocală, astfel încât acesta să reușească să devină un sunet articulat care să depășească nivelul logic și rațional și să transmită nuanțe de ordin interior care să emoționeze.

„În comunicarea umană, funcția expresivă sau emotivă dezvăluie stările interne ale emițătorului “"79, vocea și trupul fiind „principalele antene emițătoare ${ }^{\text {(80 }}$. Prezența acestei funcții surprinde un alt aport al componentei vocale ce îi conferă cuvântului capacitatea de a transmite idei și emoții prin adaptarea elementelor paraverbale prin care acesta se modelează și oferă posibilitatea de împărtăși acel rost interior. Prin prisma vocii, cuvintele alcătuite în frază reușesc să depășească ideea de simplă pronunție și enunțare și devin stimuli percepuți și interpretați de către spectator la nivel rațional și emoțional. Astfel, se poate decupa o dublă înțelegere a cuvântului, una la nivel auditiv și una la nivel lăuntric, prin capacitatea de a împărtăși prin prisma vorbirii și nuanțe ce țin de universul lăuntric al personajului, dincolo de acel bagaj informațional organizat în mesaj verbal.

78. Ibidem, p. 18.

79. Ibidem,

80. Ibidem. 
Prin perfecționare tehnică și codare lăuntrică cuvântul scris ajunge la nivel de cuvânt organic, viu, prin conectarea celor cele trei componente, trupul, gândul și sufletul acestuia, discutate și aprofundate în capitolele anterioare, un cuvânt care reflectă un sunet articulat plăcut auditiv care se rostește sub amprenta unui gând declanșator și a unei stări de spirit asumată cu adevăr. Astfel, cuvântul rostit pe scenă se ființează și reușește să surprindă acel gând viu și acea trăire autentică prin care se stabilește o conexiune tridimensională între emițător și receptor, respectiv actor-actor și actor-spectator. Se stabilește, de asemenea, o corespondență între valențele interioare ale trăirii și elementele exterioare de reprezentare, un echilibru între recognoscibil, general valabil, validat și susținut lăuntric, între cele două CUM-uri care ajută la transmiterea unei idei și a unei componente afective, un CUM tehnic armonizat de unul lăuntric.

2.4. Cuvântul „celuilalt" - de la „a fi“, „a gândi“, „a simți“, spre „a vorbi“

Din cine și cum ne apropiem de cuvântul care aparține acelei identități și dobândește o proveniență lăuntrică. Astfel, ajungem la felul de a vorbi de la asumarea interioară a unui bagaj interior ce surprinde un mod de a fi, a gândi și a simți. Prin această coordonare interioară, vocea livrează un cuvânt care comunică eficient prin validarea vocală oferită. Parcurgând etapele înmagazinării lăuntrice, se decelează acea cauză interioară care îi conferă cuvântului calitatea de a fi veridic, firesc și specific. Etapele propuse surprind pregătirea interioară imperios necesară înainte de a rosti cuvântul, astfel încât să se depășească nivelul de pronunție corectă, înglobând acel generator interior, acea coordonare care va gestiona întreg ansamblu de instrumente de expresie, fie de factură verbală, fie nonverbală. Se distinge astfel procesul interior care să controleze reprezentarea exterioară. Se poate construi, totodată, o metodă, un mecanism prin care să se realizeze un echilibru, o sincronizare între mobilarea interioară prin asumarea personalității, a gândului și a trăirii și reflectarea acestora la nivel de exprimare sau expresie. 
Astfel, problemele de tehnică vocală și de dicție pot fi privite, gestionate și lucrate dincolo de problema somatică, căutând acea cauzalitate interioară care le generează.

Astfel, se poate distinge o dublă abordare a cuvântului scris care necesită a fi rostit ca urmare a unui act de creație și prin care se livrează informații de ordin interior despre gând, trăire, personalitate.

\section{Bibliografie:}

Chelcea, Septimiu; Ivan, Loredana; Chelcea, Adina, Comunicarea nonverbală: gesturile şi postura. Cuvintele nu sunt de-ajuns, Bucureşti, Editura Comunicare.ro, 2008.

Cobley, Paul, Câte ceva despre semiotică, traducere de Alexandra Olivotto, București, Editura Curtea veche, 2004.

CoJA, Ion, „Cuvântul e semn?“" în Lucia Wald (coord.), Semantică și semiotică, București, Editura științifică și enciclopedică, 1981.

COSERIU, Eugenio, Introducere în lingvistică, traducere de Elena Ardeleanu și Eugenia Bojoga, Cluj, Editura Echinox, 1995.

Eco, Umberto, Limitele interpretării, traducere de Ștefania Mincu și Daniela Crăciun, Iași, Editura Polirom, 2016.

ECo, Umberto, Tratat de semiotică general, traducere de Anca Giurescu și Cezar Radu, Editura științifică și enciclopedică, București, 1982.

IONESCU-RUXĂNDROIU, Liliana, Conversația: structuri și strategii: sugestii pentru o pragmatică a românei vorbite, București, Editura All Educational, 1999.

IONESCU, Emil, Manual de lingvistică generală, București, Editura Bic All, 2001.

IVAN, Loredana, Cele mai importante 20 de secunde in comunicarea nonverbală, Bucureşti, Editura Tritonic, 2009.

MACREA, D., Contribuții la istoria lingvisticii și filologiei românești, București, Editura științifică și enciclopedică, 1978.

MCKAY, Matthew; DAVIs, Martha; FANNING, Patrick, Mesaje: ghid practic pentru dezvoltarea abilităţilor de comunicare, traducere de Adriana Orban, București, Editura All, 2016.

MorretTA, Angelo, Cuvântul și tăcerea, traducere de Mara și Florin Chirițescu, București, Editura Tehnică, 1994.

NoICA, Constantin, Cuvânt împreună despre rostirea românească, București, Editura Eminescu, 1987. 
PAVIS, Patrice, Dictionaire du théâtre, Paris, Dunod Éditeur, 2019.

PITAR, Mariana, Textul injonctiv: repere teoretice, Timișoara, Editura Excelsior Art, 2007.

PRUTIANU, Ştefan, Antrenamentul abilităților de comunicare, Editura Polirom, Iaşi, 2004.

SCHVEIGER, Paul, O introducere în semiotică, București, Editura Științifică și enciclopedică, 1984.

SFÎRlEA, Lidia, Pronunția românească literară - stilul scenic, București, Editura Academiei Republicii Socialiste Române, 1970.

STĂNCIUgelu, Irina; Tudor, Raluca; TRAN, Adriana; VASIle Tran, Teoria comunicării, Bucureşti, Editura Tritonic, 2014.

STROE Marcus, Empatie și personalitate, București, Editura Atos, 1997.

TовоȘARU, Ion, Principii generale de estetică, Cluj-Napoca, Editura Dacia, 1978.

TOHĂNEANU, G. I., Dincolo de cuvânt, București, Editura științifică și enciclopedică, 1976.

ZDRENGHEA, Mircea, Studii lingvistice, Alba Iulia / Cluj-Napoca, Editura Altip/Editura Scriptor, 2014. 